\title{
OCEANOGRAPHIC CHARACTERISTICS OF KLABAT BAY, BANGKA ISLAND, INDONESIA
}

\author{
Suhendar I Sachoemar ${ }^{1 *}$, Agus Kristijono ${ }^{1}$ and Tetsuo Yanagi ${ }^{2}$ \\ ${ }^{1}$ Agency for the Assessment and Application of Technology (BPPT) \\ Jl. M.H. Thamrin No. 8, BPPT, Jakarta 10340, Indonesia \\ *e-mail : sachoemar@yahoo.com \\ ${ }^{2}$ Research Institute for Applied Mechanics (RIAM), Kyushu University \\ Kasuga-koen, Kasuga-shi 1-6, Fukuoka, Japan
}

\begin{abstract}
The oceanographic characteristics of Klabat Bay in Bangka Island of Indonesia were investigated by using a series of temperature, salinity, turbidity, TSS (total suspended solid), transparency, DIN (Dissolved Inorganic Nitrogen), DIP (Dissolved Inorganic Phosphorus), DO (Dissolved Oxygen) and chlorophyll- $a$ data in the wet season (Northwest Monsoon) and dry season (Southeast Monsoon) of 2003, respectively. The observation results show that the hydro-oceanographic characteristics of Klabat Bay in the inner part and the outer part of the bay were dominantly influenced by the terrestrial and oceanic environment, respectively. High precipitation during the wet season decreased salinity, DO and transparency and increased total suspended solid (TSS), turbidity, DIN and chlorophyll- $a$ within the bay. The reverse occurred during the dry season, except DIP.
\end{abstract}

Keywords: Oceanographic characteristics, Klabat Bay, Natuna Sea.

\section{INTRODUCTION}

Klabat Bay is a semi enclosed ecosystem that is separated into two sections by the narrow channel in the middle part. This bay is situated in the northern coastal area of Bangka Island and faces directly to the Natuna Sea in the northern part, while in the southern part connected to the Java Sea (Fig.1). The depth of the water in the inner part (K-I) is relatively shallow compared to the outer part (K-II) due to high amount of sediments supplied by seven rivers in which two rivers among them are relatively big i.e. Layang river in the southern part and Antan river in the western part. The outer part of the bay was dominantly influenced by the neritic environment of the Natuna Sea.

As a tropical area located between Asia and Australia, the environmental situation of Klabat Bay is affected by the monsoonal system that influences its hydro-oceanographic characteristics. During the northwest monsoon, the environment is dominantly influenced by the South China Sea and in the southeast monsoon by the Java Sea. The surface current speed within this area varied from $0.3 \mathrm{~m} /$ $\mathrm{s}$ to $1.9 \mathrm{~m} / \mathrm{s}$ with high and low current speed occurred during the northwest and southeast monsoon, respectively (Anonymous, 2000a). The terrestrial environment variability surrounding the bay is affected by the meteorological situation that is associated with the monsoonal variation, i.e different intensity of the winds and the amount of precipitation (Anonymous, 2000b).

For centuries, Bangka Island is well known for its tin mining area. Intensive development of the mining and excessive exploitation of the resources have caused serious degradation in both terrestrial and water resources of the Island. This negative impact may be seen in the large increase of the number of fresh water ponds in the Bangka Island. The similar impact is also seen in the water body of Klabat Bay and the rivers, especially since the conventional, illegal and destructive tin mining activity has been growing up in this area in recent years. Consequently, the environment of Klabat Bay has much degraded, in spite of the fact that the local government has promoted this area as potential source for fisheries development. 


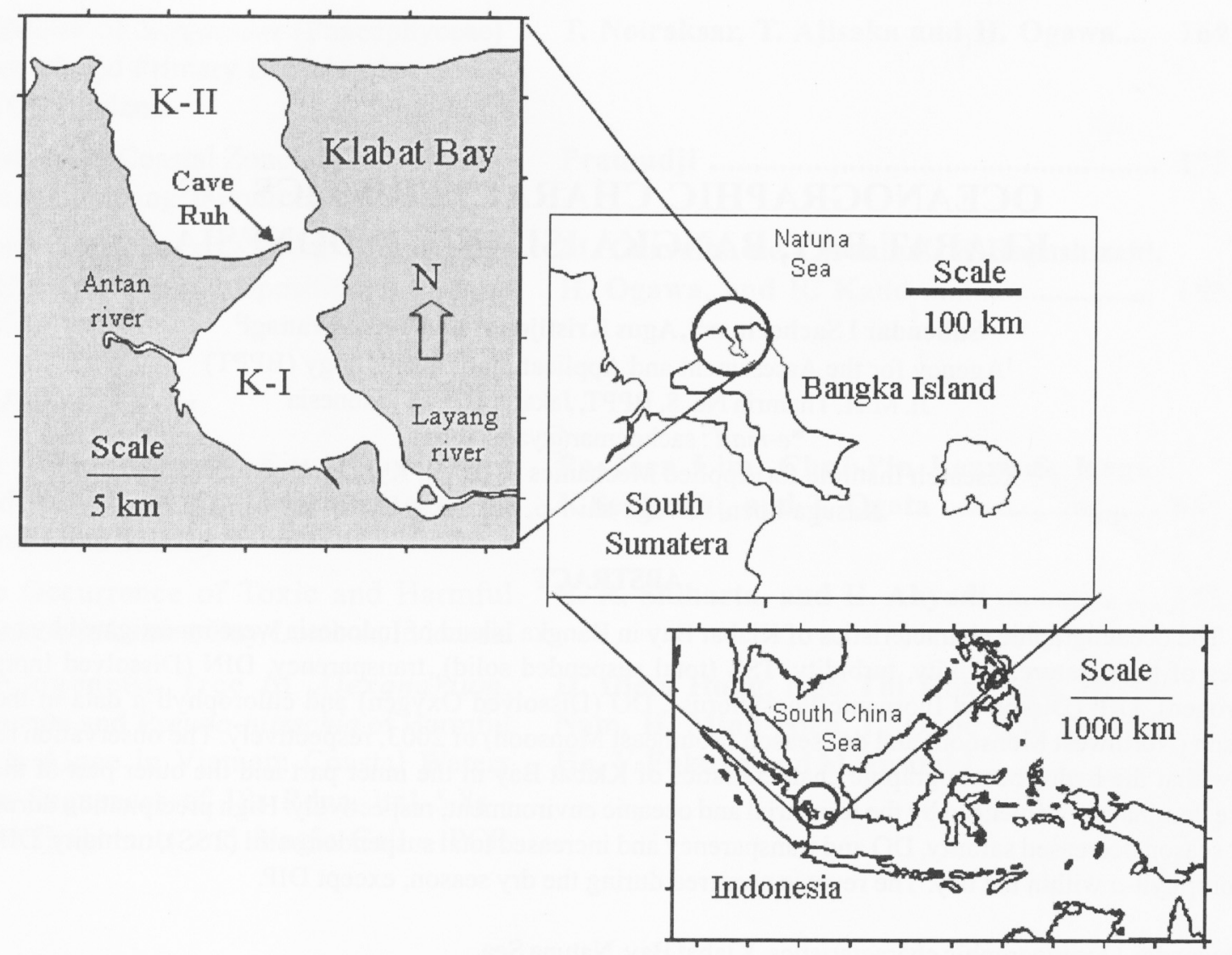

Figure1. Study area of Klabat Bay, Bangka Island. K-I and K-II are inner and outer parts of the bay, respectively.

Currently, the existing information concerning the environmental situation at Klabat Bay is still limited and is mostly focused on the estuary of Antan and Layang rivers, the inner part of Klabat Bay (Nomosatryo et al., 2004; Rosidah and Hartoto, 2004; Syawal and Hartoto, 2004; Sudarso, 2004; Sulastri, 2004; and Ridwansyah et al., 2004). To support the implementation program of the water resource use of Klabat Bay, the oceanographic study to understand the hydro-oceanographic characteristics of this area is important and necessary.

\section{METHOD}

A series of physical (temperature, salinity, turbidity, TSS - total suspended solid, transparency), chemical (DIN-dissolved inorganic nitrogen, DIP-dissolved inorganic phosphorus) and biochemical (DO-dissolved oxygen and chlorophyll- $a$ ) data in the wet season (Northwest Monsoon) and dry season (Southeast Monsoon) of 2003 were collected to understand the hydrooceanographic status of Klabat Bay. Water samples were taken using Nansen bottle from the surface and near the bottom at 17 stations of Klabat Bay (Fig.2). Water temperature, salinity, turbidity and DO was measured directly in the field by using water quality checker Horiba U 10 (Bengen, 2000), transparency was measured by secchi disk and the nutrients were analyzed by using spectrophotometer of Spectronic 21 D Milton and Spectro 2000 RS Labomed (APHA, 1989). The water depth of Klabat Bay is within the range of 1.5 to $13 \mathrm{~m}$ depth, with the tidal range about 2 $\mathrm{m}$.

\section{RESULTS AND DISCUSSION}

\section{Temperature, salinity, turbidity, total suspended solid (TSS) and transparency}

Spatial-temporal variability of water temperature, salinity, turbidity, TSS and transparency in the inner part (K-I) and outer part (K-II) of Klabat Bay was shown in Fig.3. During the wet season, water temperature, turbidity and TSS was higher than those during the dry season. 


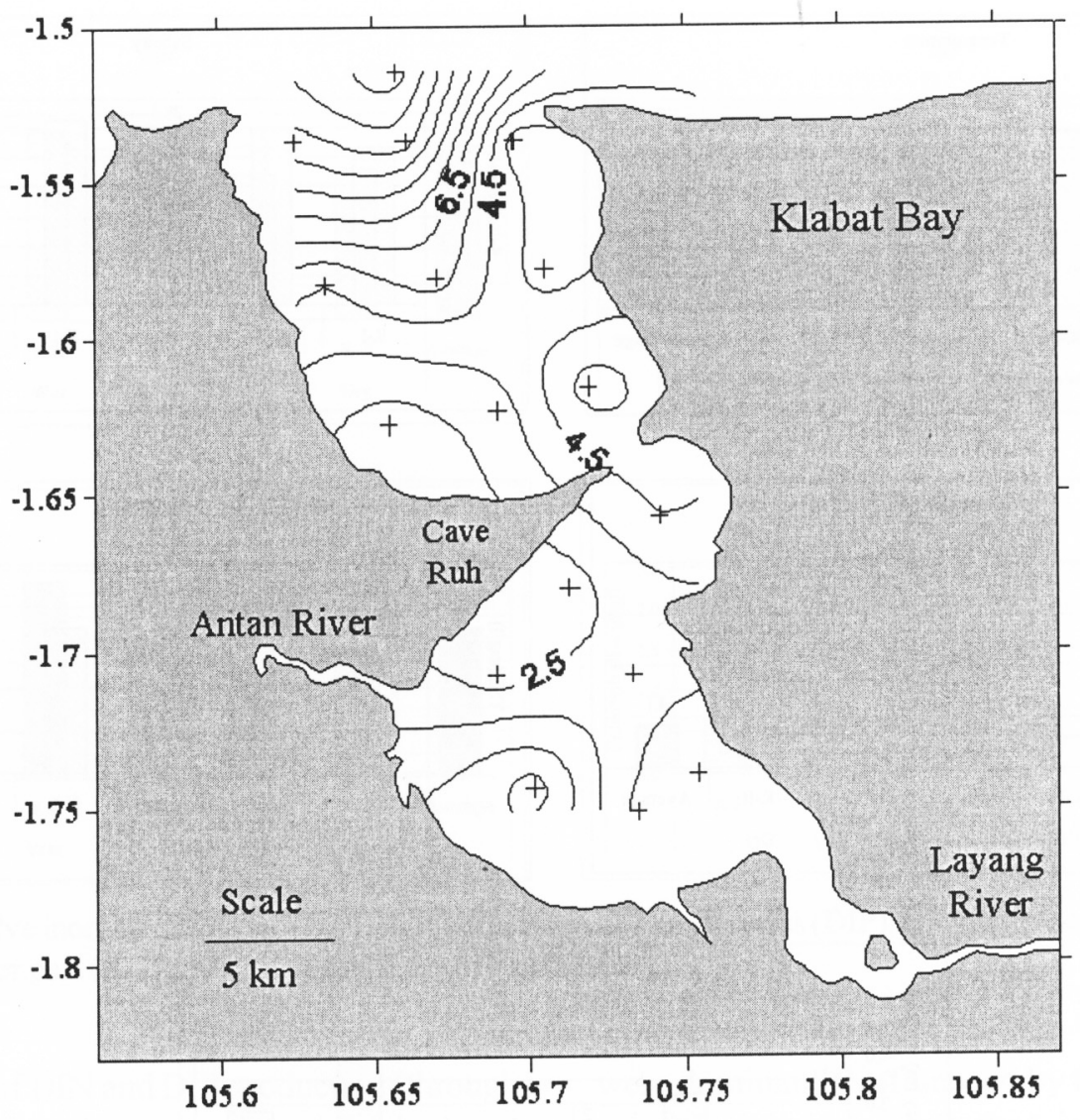

Figure 2. Bathymetry and sampling stations (+ marks) at Klabat Bay

High precipitation occurred during the northwest monsoon (Fig. 4) seems to have supplied more sediment load than that during the dry season. In the inner part of the bay, water temperature in the wet season was lower than that in the outer part. It might be due to the decreasing water temperature of the Antan and Selayang rivers due to high precipitation. The interesting situation was seen on the TSS concentration of the outer part in the dry season. Due to presence of the floating tin mining activity in the outer part of Klabat Bay, the water quality within this area should have been degraded and turbid, particularly in the western part of the outer bay where this activity is concentrated. However, the water transparency within this area is still better than that in the inner part in both dry and wet seasons.

It is thought that the lower water temperature during the wet season, the higher turbidity and TSS, together with the lower transparency in both seasons of K-I area compared to those of the KII area, is due to the fact that the K-I area is more confined than the more opened K-II area. Cape Ruh (Fig.1) effectively cut off the mixing process between two areas. Moreover, Cape Ruh has a significant extent to prevent good water circulation between the K-I and K-II areas, so that contribution of terrestrial particles in increasing TSS and turbidity in the K-I area could not be seen in the K-II area. The same factor causes the lowering of K-I transparency, though not so intense as the TSS and turbidity variability. The transparency in the K-II area is significantly higher in both seasons compared to that of the K-I area. Again this condition is due to the confinement of K-I area and openness of K-II area to the Natuna Sea.

\section{DIN, DIP, DO and Chlorophyll-a}

Generally there are no significant differences in the concentrations of DIN and DIP both in regard to the monsoons and to K-I area against $\mathrm{K}$-II area (Fig.5). However this is not the case in regard to DO and chlorophyll-a concentrations. It seems that both DIN and DIP are more or less constant both in regard to area and to monsoon. In the case of K-I area, this case may be due to 

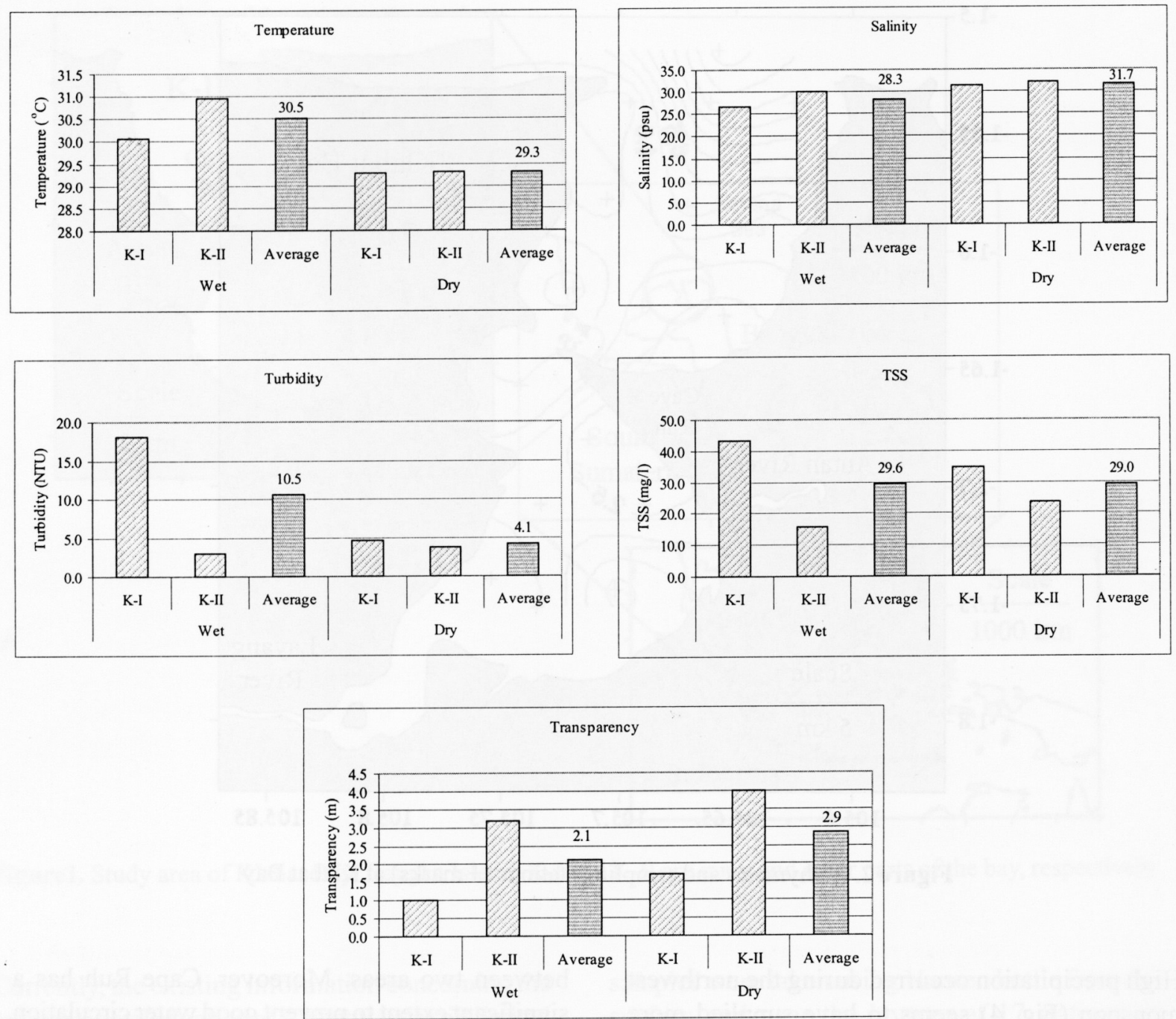

Figure 3. Water temperature, salinity, tubidity, total suspended solid (TSS) and transparency variability at inner part (K-I) and outer part (K-II) of Kalabat Bay.

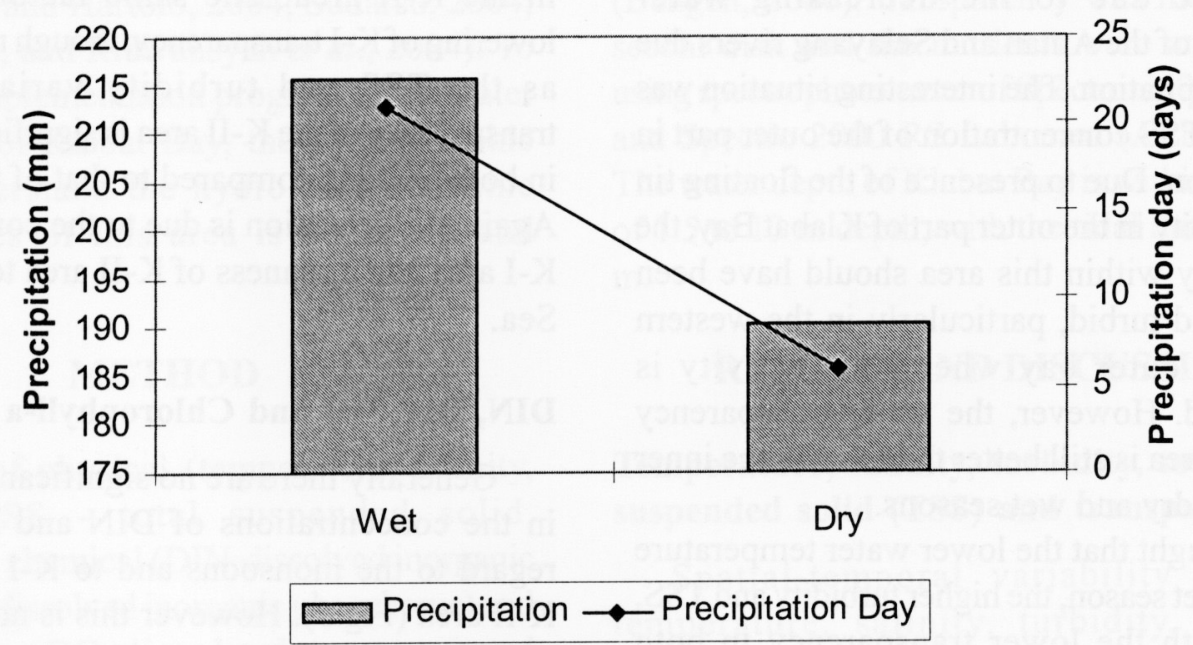

Figure 4. Precipitation and precipitation day at Klabat Bay in 2003, reproduced from Anonymous ${ }^{\mathrm{c}}$ (2004). 

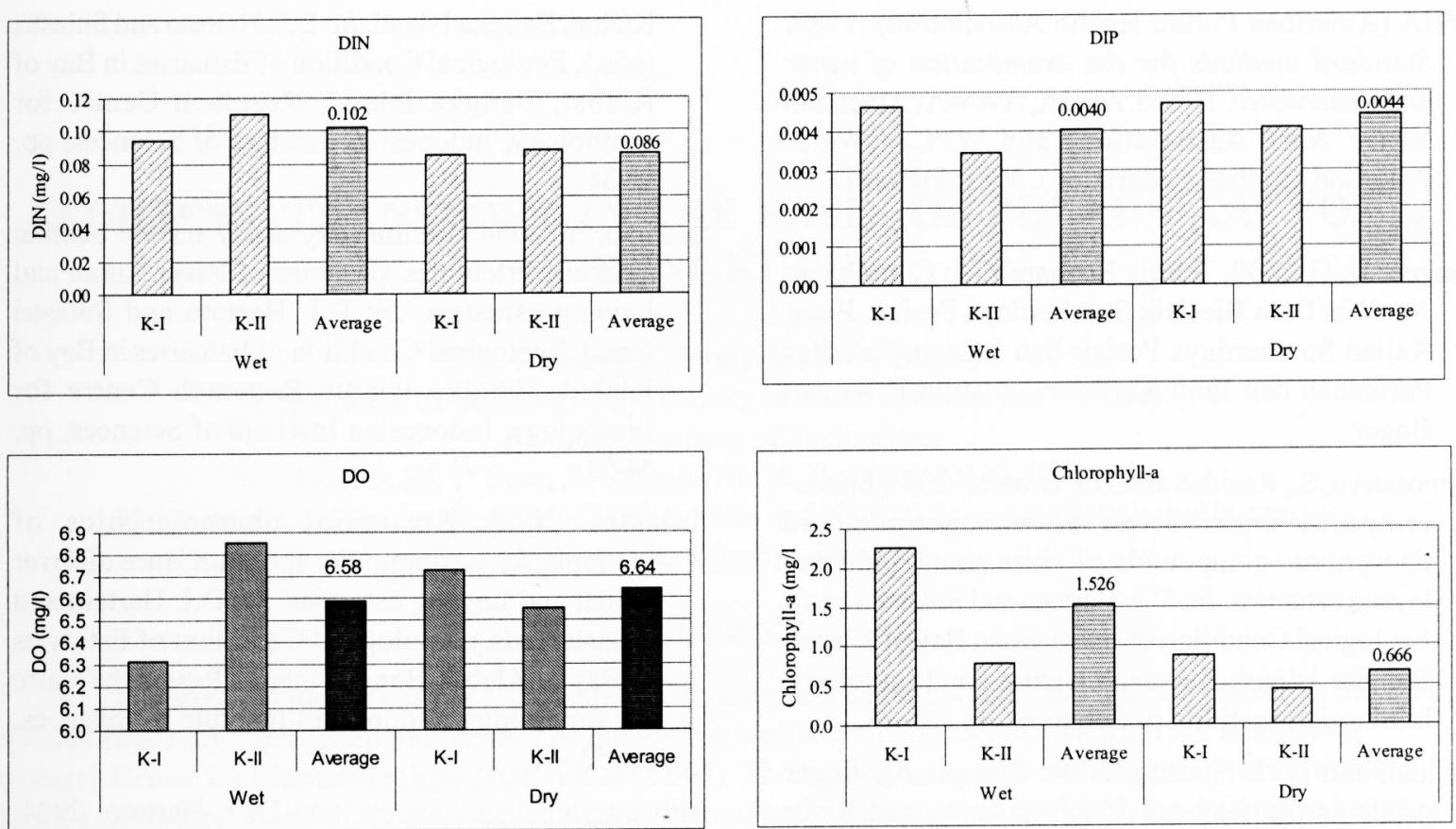

Figure 5. Dissolve inorganic nitrogen (DIN), dissolve inorganic phosphorous (DIP), chlorophyll-a and DO variability at inner part (K-I) and outer part (K-II) of Kalabat Bay.

the same level of DIN and DIP production (through bacterial release and terrestrial contribution) and their utilization (by phytoplankton through photosynthesis). In the case of K-II area, the small variability in the DIN and DIP values is maintained by its good water circulation with the water coming from the Natuna Sea

$\mathrm{DO}$ is very low in the K-I area during the wet season. This fact may indicate the utilization of DO by bacteria to decompose old organic material from the land, among those transported by the Layang and Antan rivers. A part of these organic material may be in the form of particle, thus may contribute to the increase of TSS and turbidity, and to the decrease of transparency of K-I area during the wet season (Fig.3).

Chlorophyll- $a$ in K-I area is consistently higher than that in K-II area, and especially during the wet season (Fig.5). This case might be due to the enhanced growth of phytoplankton, caused by nutrient released by bacterial decomposition of organic matter transported to this area, either directly through land drainage, or by river's transportation.

\section{CONCLUSION}

The oceanographic characteristic of Klabat Bay in the inner part and the outer part of the bay were dominantly influenced by the terrestrial and oceanic environment that is controlled by monsoonal systems. High precipitation during the wet season decreased salinity, DO and transparency and increased total suspended solid (TSS), turbidity, DIN and chlorophyll- $a$ within the bay. The existence of the cape in the middle part of the bay has effectively contributed. on the cut off the mixing process between two areas, and it prevented the intrusion of TSS and turbidity from the inner part to the outer part of the bay during the wet season. The presence of the floating tin mining activity in the outer part of Klabat Bay, has caused the water quality within this area to be degraded and turbid.

\section{REFERENCE}

Anonymous. 2000a. Data dasar wilayah pesisir dan kelautan Kabupaten. Pemerintah Kabupaten Bangka Bekerjasama dengan Sekolah Tinggi Teknologi Angkatan Laut.

Anonymous. 2000b. Inventarisasi sumberdaya kelautan Kabupaten Bangka. Kerjasama Universitas Sriwijaya dengan Pemerintah Kabupaten Bangka.

Anonymous. 2004. Bangka Dalam Angka 2003. Kerjasama Badan Pusat Statistik Kabupaten Bangka dengan Badan Perencanaan Pembangunan Daerah Kabupaten Bangka. 
APHA (American Public Health Association). 1989. Standard methods for the examination of water and wastewater. $17^{\text {th }}$ ed. APHA, AWWA(American Water Work Association) and WPCF (Water Pollution Control Federation). Washington D. C. 3464p.

Bengen, D. G. 2000. Tehnik Pengambilan Contoh dan Analisis Data Biofisik Sumberdaya Pesisir. Pusat Kajian Sumberdaya Pesisir dan Lautan. Fakultas Perikanan dan Ilmu Kelautan. Institut Pertanian Bogor.

Nomosatryo, S., Rosidah and D.I. Hartoto. 2004. Spatiotemporal distribution of nitrogenous and phosphorus compounds of river antan and river layang estuaries. In: D.I. Hartoto and Sulastri (eds.), Ecological Condition of Estuaries in Bay of Klabat, Bangka Island, Reserach Centre for Limnology, Indonesian Institute of Sciences, pp. 16-27.

Rosidah and D. I. Hartoto. 2004. Phosphorus finger prints as the features of River Antan and River Layang estuaries. In: D.I. Hartoto and Sulastri (eds.), Ecological Condition of Estuaries in Bay of Klabat, Bangka Island, Reserach Centre for Limnology, Indonesian Institute of Sciences, pp. 35-43.

Syawal, M. S. and D. I. Hartoto. 2004. A study on heavy metal pollution in river water in estuaries of Teluk
Klabat, Bangka Island. In: D.I. Hartoto and Sulastri (eds.), Ecological Condition of Estuaries in Bay of Klabat, Bangka Island, Reserach Centre for Limnology, Indonesian Institute of Sciences, pp. 28-34.

Sudarso, Y. 2004. Preliminary study on the benthic macroinvertebrates structure of River Antan and Layang estuaries. In: D.I. Hartoto and Sulastri (eds.), Ecological Condition of Estuaries in Bay of Klabat, Bangka Island, Reserach Centre for Limnology, Indonesian Institute of Sciences, pp. 44-52.

Sulastri. 2004. Structural characteristics of phytoplankton community and abundance of River Antan and Layang estuaries. In: D.I. Hartoto and Sulastri (eds.), Ecological Condition of Estuaries in Bay of Klabat, Bangka Island, Reserach Centre for Limnology, Indonesian Institute of Sciences, pp. 53-61.

Ridwansyah, I., L. Subehi and D. I. Hartoto. 2004. Geomorphological study for conservation and sustainable management of biota in the bay of Klabat. In: D.I. Hartoto and Sulastri (eds), Ecological Condition of Estuaries in Bay of Klabat, Bangka Island, Reserach Centre for Limnology, Indonesian Institute of Sciences, pp. 1-15. 